\title{
PENINGKATAN UNJUK KERJA SISTEM TRANSMISI KOMUNIKASI DIGITAL PADA PENERIMA DENGAN MENGGUNAKAN TEKNIK DIVERSITY EQUAL GAIN COMBINING
}

\author{
Baharuddin* dan Ondri Yudha Rusli \\ Jurusan Teknik Elektro, Fakultas Teknik, Universitas Andalas \\ *Corresponding author, e-mail : baharuddin.abbas@ft.unand.ac.id
}

\begin{abstract}
Abstrak - Pada sistem komunikasi digital, adanya fading dan noise di kanal akan mengganggu maupun menurunkan kinerja sistem komunikasi digital. Dimana gangguan ini dapat menyebabkan terjadinya kesalahan pendeteksian sinyal, sehingga dapat terjadi perubahan bit atau simbol pada sisi penerima. Dengan menerapkan teknik diversity equal gain combining pada sisi penerima, maka dapat ditingkatkan kinerja dari sistem komunikasi digital tersebut. Melalui simulasi dalam penelitian ini telah dianalisa pengaruh penerapan teknik diversity equal gain combining pada sistem yang terkena noise AWGN dan fading Rayleigh. Besarnya pengaruh dari teknik diversity equal gain combining yang digunakan dapat diketahui melalui analisa BER. Hasil simulasi dari penelitian ini menunjukkan bahwa, adanya peningkatan perbaikan sistem dipenerima rata rata dua kali lebih baik bila dibandingkan dengan tanpa menggunakan teknik diversity equal gain combining.
\end{abstract}

Kata kunci : Diversity Equal Gain Combining, Noise AWGN, Fading Rayleigh, BER

\begin{abstract}
In digital communication systems, the presence of fading and noise in the channel will disrupt or degrade the performance of digital communication system. This disruption may cause error on signal detection and may cause bits change or symbols at the receiver. By applying Equal Gain combining diversity techniques at the receiver, it can improve the digital communication system performance. Through simulation, this study analyzed the effect of applying equal gain combining diversity techniques on the system that affected by noise AWGN and Rayleigh fading. Performance evaluation on the use of equal gain combining diversity technique can be determined through BER analysis. The simulation result of this study indicates that there is improvement on system performance at the receiver twice better than without utilizing equal gain combining diversity technique.
\end{abstract}

Keywords : Diversity Equal Gain Combining, Noise AWGN, Fading Rayleigh, BER

Copyright $\odot 2016$ JNTE. All rights reserved

\section{PENDAHULUAN}

Dewasa ini kemajuan dalam bidang teknologi telekomunikasi berkembang dengan pesat, khususnya pada telekomunikasi wireless [1]. Hal tersebut didukung oleh perkembangan teknologi perangkat komunikasi portabel, yang telah memungkinkan untuk melakukan pertukaran informasi multimedia (data, suara, citra, dan video) yang saat ini menjadi populer dan sangat disenangi. Diantara informasiinformasi multimedia tersebut, pemakaian citra merupakan salah satu fitur yang penting dan telah digunakan secara luas dalam berbagai aplikasi, seperti pada internet, citra medis, kamera keamanan jarak jauh, MMS (Multimedia Messaging Service), dan beragam aplikasi lainnya. Hal tersebut mengindikasikan bahwa pada saat ini pemakaian sistem transmisi citra secara wireless sangat diminati dan terus berkembang.

Pada transmisi melalui kanal wireless terdapat hal-hal yang bisa menyebabkan penurunan kualitas informasi yaitu noise dan fading [2]. Gangguan-gangguan tersebut dapat menyebabkan kesalahan penerimaan informasi pada sisi penerima. Gangguan-gangguan tersebut bersifat acak dan tidak bisa diprediksi secara pasti kemunculannya. Sehingga diperlukan suatu teknik untuk memperbaiki kualitas sinyal agar didapatkan sinyal dengan kualitas baik pada penerima [3-4].

Penggunaan sistem komunikasi digital dalam bidang komunikasi radio bergerak semakin meningkat, sehingga diperlukan suatu sistem komunikasi yang handal guna menjamin 
sampainya pesan atau data yang benar pada penerima. Pada kanal komunikasi, adanya fading akan mengganggu maupun menurunkan kinerja sistem komunikasi digital. Hal ini menyebabkan terjadinya kesalahan pendeteksian sinyal sehingga terjadi perubahan bit atau simbol pada sisi penerima. Akibat dari adanya fading tersebut, maka kinerja sistem akan menurun. Untuk itu dibutuhkan suatu sistem yang dapat memperbaiki unjuk kerja sistem pada penerima. Untuk mengatasi hal tersebut dipenerima ditambahkan salah satu teknik diversity yaitu teknik diversity equal gain combining [4-6].

Pada tahun 2004, Hafeth Hourani melakukan penelitian mengenai teknik-teknik untuk mengatasi fenomena fading dan noise pada kanal wireless yang dituangkan dalam jurnalnya An Overview of Diversity Techniques in Wireless Communication Systems. Ia mengemukakan teknik diversity sebagai salah satu cara untuk mengatasi fading dan noise pada transmisi melalui kanal wireless [2].

Beberapa penelitian tentang transmisi citra melalui kanal wireless telah dilakukan antara lain oleh Liane C Ramac dan Pramod K Varshney dalam jurnal mereka yang berjudul $A$ Wavelet Domain Diversity Method for Transmission of Images over Wireless Channels, yang menggunakan teknik diversity yang berada pada domain wavelet untuk mendapatkan citra rekonstruksi yang baik [8]. Pada transnmisi citra ini model kanal yang digunakan adalah two-state Gilbert-Elliott channel [3]. Serta Nikolaos Thomos, Nikolaos V Boulgouris, dan Michael G Strinzis dengan jurnal mereka yang berjudul Wireless Image Transmission Using Turbo Codes and Optimal Unequal Error Protection, yang menggunakan Turbo Codes untuk melindungi citra selama transmisi [10], juga $\mathbf{P}$ G Sherwood dan K Zeger dengan jurnal mereka yang berjudul Error Protection for Progressive Images Transmission over Memoryless and Fading Channels, yang menggunakan teknik perlindungan data selama transmisi [12].

Pada penelitian ini digambarkan suatu simulasi yang menerapkan teknik diversity equal gain combining pada penerima. Sistem ini memakai teknik modulasi Binary Phase Shift Keying (BPSK) dan jumlah kanal yang dipakai adalah dua, serta setiap kanal dipengaruhi oleh noise (Additife White Gaussian Noise) AWGN dan fading yang berdistribusi Rayleigh [4-6].

Sedang teknik Equal gain combining mengacu pada Baharuddin [4]. Berdasarkan penelitian yang telah dilakukan diatas, maka dalam penelitian ini berjudul "Peningkatan Unjuk Kerja Sistem Transmisi Komunikasi Digital Pada Penerima Dengan Menggunakan Teknik Diversity Equal Gain Combining. Penelitian ini menghasilkan unjuk kerja transmisi data digital mengalami peningkatan bila menggunakan teknik diversity equal gain combining dibandingkan dengan tanpa sistem tersebut.

\section{TINJAUAN PUSTAKA}

\subsection{Noise AWGN}

Model kanal yang digunakan adalah Noise AWGN (Additive White Gaussian Noise). Noise ini berdistribusi normal dengan nilai rata-rata (mean) nol. Noise ini bernilai acak dan bersifat menambahkan sinyal aslinya. Bentuk persamaan pdf dari distribusi Gaussian adalah [12-13]:

$$
p(x)=\frac{1}{\sqrt{2 \pi} \sigma} e^{-\left(x-m_{x}\right)^{2} / 2 \sigma^{2}}
$$

dimana :

$m_{x}=$ mean

$\sigma^{2}=$ varians dari variable random

\subsection{Fading Rayleigh}

Pada kanal wireless, distribusi Rayleigh secara umum dipakai untuk menggambarkan statistik perbedaan waktu dari envelope yang diterima untuk sebuah sinyal flat Fading. Fading cepat merupakan Rayleigh Fading karena Fading ini terdistribusi mengikuti distribusi Rayleigh, yang mempunyai fungsi kepadatan probabilitas seperti yang ditunjukkan persamaan (2) [8]

$$
p\left(r_{a}\right)=\left\{\begin{array}{cc}
\frac{r_{a}}{\sigma^{2}} \exp \left(-\frac{r_{a}^{2}}{2 \sigma^{2}}\right) & \left(0 \leq r_{a} \leq \infty\right) \\
0 & \left(r_{a}<0\right)
\end{array}\right.
$$

dimana :

$$
\begin{aligned}
& \sigma=\text { tegangan rata }- \text { rata } \\
& \sigma^{2}=\text { daya rata-rata }
\end{aligned}
$$


Fungsi distribusi kumulatif menyatakan presentasi lebih kecil dari nilai $R_{a}$ tertentu, yang diperoleh dengan melakukan integral terhadap fungsi rapat peluang $p\left(r_{a}\right)$ [12-14].

$P\left(R_{a}\right)=P_{r_{a}}\left(r_{a} \leq R_{a}\right)=\int_{0}^{R_{a}} p\left(r_{a}\right) d r_{a}=1-\exp \left(-\frac{R_{a}^{2}}{2 \sigma^{2}}\right)$

$r_{a_{\text {mean }}}$ distribusi Rayleigh adalah :

$r_{a_{\text {mean }}}=E\left[r_{a}\right]=\int_{0}^{\infty} r_{a} p\left(r_{a}\right) d r_{a}=\sigma \sqrt{\frac{\pi}{2}}=1,2533 \sigma$

$\sigma_{r_{a}}^{2}$ merupakan varians dari distribusi Rayleigh yang mewakili daya ac pada selubung sinyal.

$$
\begin{aligned}
\sigma_{r_{a}}^{2} & =E\left[r_{a}^{2}\right]-E^{2}\left[r_{a}\right]=\int_{0}^{\infty} r_{a}^{2} p\left(r_{a}\right) d r_{a}-\frac{\sigma^{2}}{2} \\
& =\sigma^{2}\left(2-\frac{\pi}{2}\right)=0,4292 \sigma^{2}
\end{aligned}
$$

Untuk menghitung nilai tengah untuk $r_{a}$, dapat digunakan persamaan (4).

$\frac{1}{2}=\int_{0}^{r_{a_{\text {median }}}} p\left(r_{a}\right) d r_{a} \Rightarrow r_{a_{\text {median }}}=1,177 \sigma$

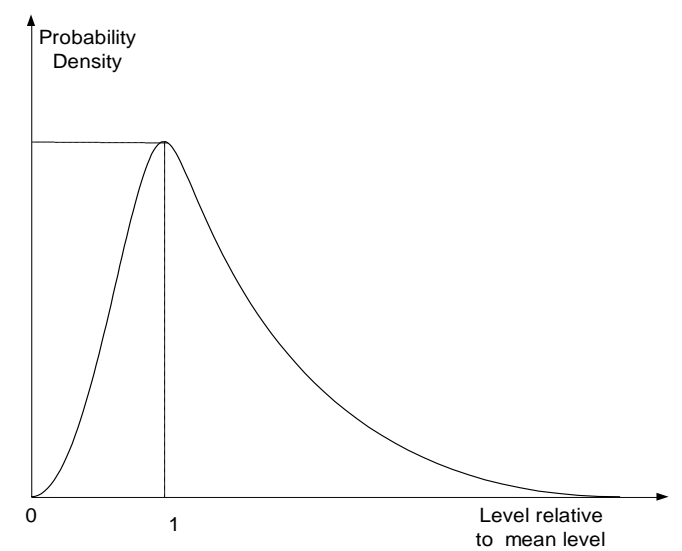

Gambar 1. Grafik Pdf Distribusi Rayleigh [4-5].

Jadi terdapat perbedaan nilai rata-rata dan nilai tengah sebesar $0,55 \mathrm{~dB}$ dalam distribusi Rayleigh[3]. Sebagai catatan bahwa nilai tengah pada prakteknya sering digunakan, karena data Fading biasanya diukur dilapangan dan kenyataannya distribusinya tidak dapat diasumsikan. Dengan penggunaan nilai tengah sebagai pengganti nilai rata - rata maka mudah kita membandingkan distribusi Fading yang berbeda dan memiliki nilai tengah yang bermacam-macam. Envelope sinyal Fading yang dibangkitkan merupakan proses kompleks gaussian yang mempunyai bagian real yang independen dengan bagian imajinernya. Pada gambar 1 ditunjukkan grafik Pdf (Probability Density Function) dari sebuah distribusi Rayleigh [11, 13-14].

\subsection{Teknik Equal Gain Combining}

Pada equal gain combining, semua sinyal di co-phase kemudian dijumlahkan tanpa diberi pembobot, maka untuk dua cabang diversity dapat dibuat model seperti pada gambar berikut:

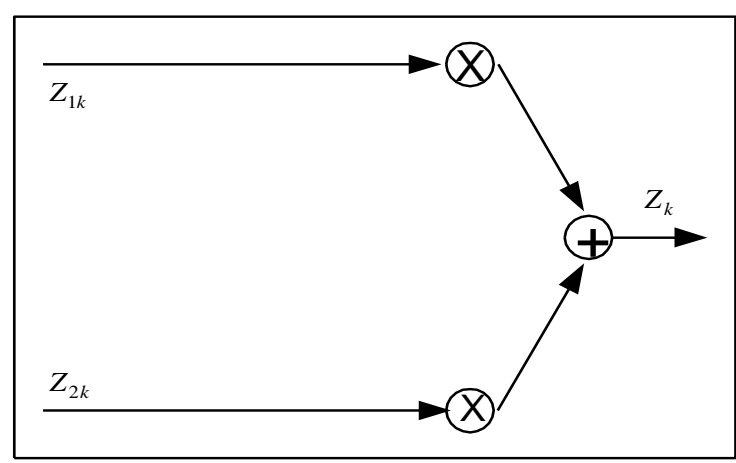

Gambar 2. Model Sistem untuk Equal Gain Combining [4-5, 11].

Sinyal dari semua cabang di co-phase dan masing-masing diberi bobot untuk menyediakan SNR yang optimal pada sisi output. Gambar 3, menunjukkan blok diagram dari metode ini, dimana ada $M$ cabang yang masuk ke rangkaian dan setiap cabang memiliki gain tertentu.

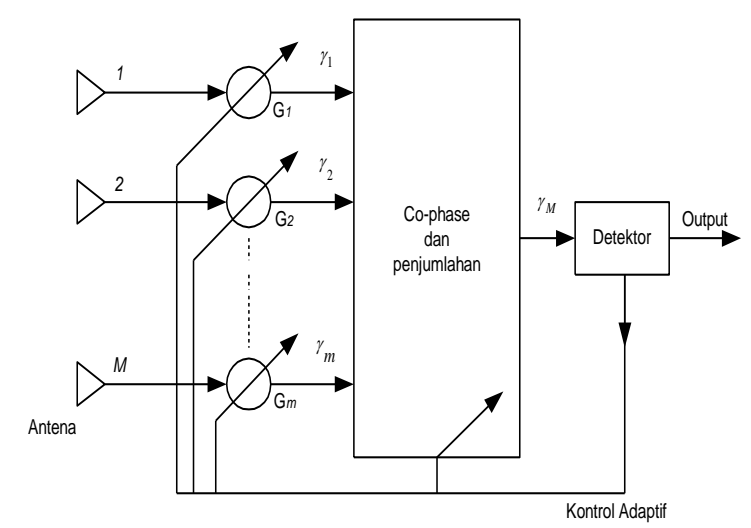

Gambar 3. Blok diagram model sistem Equal gain combining [5,11]. 
Untuk semua cabang $M$, jika masingmasing cabang memiliki sinyal tegangan $r_{i}$ serta gain untuk cabang ke- $i$ adalah $G_{i}$, maka selubung sinyal combiningnya adalah $[5,11]$.

$$
r_{M}=\sum_{i=1}^{M} G_{i} r_{i}
$$

Dari persamaan (7), karena $G_{i}=1$, maka untuk $M$ cabang combining, akan diperoleh selubung sinyal output gabungan sebesar :

$$
r_{M}=\sum_{i=1}^{M} r_{i}
$$

Dengan mengasumsikan daya noise ratarata yang dimiliki oleh setiap cabang adalah $N_{i}$, maka total daya noise $N_{T}$ pada detektor menjadi $[5,11]$ :

$$
N_{T}=\sum_{i=1}^{M} N_{i}
$$

Pada kanal fading yang gainnya terdistribusi Rayleigh dengan harga mean ternormalisasi sehingga $\Gamma$ adalah seperti pada persamaan (10), dimana $\Gamma$ adalah $S N R$ rata-rata dari setiap cabang. Probabilitas bahwa sebuah cabang memiliki SNR kurang dari nilai threshold $\gamma$ adalah $[5,11]$ :

$$
\begin{aligned}
P_{r}\left[\gamma_{i} \leq \gamma\right] & =\int_{0}^{\infty} p\left(\gamma_{i}\right) d \gamma_{i}=\int_{0}^{\infty} \frac{1}{\Gamma} e^{\frac{-\gamma_{i}}{\Gamma}} d \gamma_{i} \\
& =1-e^{\frac{-\gamma_{i}}{\Gamma}}
\end{aligned}
$$

maka $p d f$ dari output $S N R$ adalah [13-14]:

$$
p\left(\gamma_{M}\right)=\frac{2^{M-1}}{(2 M-1) !} \frac{1}{\prod_{k=1}^{M}\left(N_{i} / N_{t}\right)} \frac{\gamma_{M}{ }^{M-1}}{\prod_{k=1}^{M} \Gamma}
$$

Pada persamaan di atas $\Gamma$ adalah $S N R$ pada beberapa cabang diversity yang independen terhadap gain dari cabang- cabang tersebut.

Untuk memaksimalkan performansi equal gain combiner, dengan harapan meminimalkan $p\left(\gamma_{M}\right)$ secara uniform maka dilakukan dengan menaikkan faktor denominatornya. Tapi karena persamaan :

$$
\sum_{k=1}^{M} \frac{N_{i}}{N_{T}}=1
$$

Maka persamaan tersebut bisa dikondisikan sebagai $M$ factor yang memiliki hasil maksimal sama dengan satu, sehingga faktor dari masing-masing cabang adalah $1 / M$. Dengan demikian melalui pengkondisian seperti ini performansi terbaik akan bisa diperoleh dengan mengatur gain pada setiap cabang untuk level noise yang sama pada input combiner. Dengan ini diasumsikan bahwa $[5,11]$ :

$$
\sum_{k=1}^{M} \frac{N_{i}}{N_{T}}=\left(\frac{1}{M}\right)^{M}
$$

Sehingga persamaan (13) akan menjadi [11] :

$$
p\left(\gamma_{M}\right)=\frac{2^{M-1} M^{M}}{(2 M-1) !} \frac{\gamma_{M}{ }^{M-1}}{\prod_{k=1}^{M} \Gamma}
$$

\section{METODOLOGI}

Metode penelitian yang digunakan dalam penelitian ini adalah metode eksperimental. Menurut [16], penelitian eksperimental merupakan observasi di bawah kondisi buatan, dimana kondisi tersebut dibuat dan diatur oleh peneliti dan penelitian dilakukan dengan melakukan manipulasi terhadap objek penelitian serta adanya kontrol.

\subsection{Sampel Penelitian}

Sampel penelitian yang digunakan adalah pembangkitan bit-bit informasi secara acak sebanyak jumlah bit yang diinginkan. Pada simulasi ini dibangkitkan sebanyak 10000 bit dengan menggunakan perintah rand(1,10000)>0,5 pada Matlab sehingga diperoleh urutan bit yang nilainya antara ' 0 ' dan ' 1 '. Kemungkinan muncul bit ' 1 ' dan bit ' 0 ' adalah sama besar dan saling bebas [11].

Terhadap bit-bit yang dibangkitkan tersebut dilakukan proses modulasi dengan menggunakan teknik modulasi BPSK, dimana bit-bit ini diubah ke level '-1' yang mewakili bit ' 0 ' dan level ' 1 ' yang mewakili bit ' 1 '. Selanjutnya simbol-simbol ini diubah menjadi sinyal persegi yang dapat ditransmisikan sepanjang kanal [7]. 


\subsection{Desain Penelitian}

Penelitian dilakukan dengan merancang sebuah sistem transmisi digital. Model simulasi untuk sistem yang akan disimulasikan adalah :

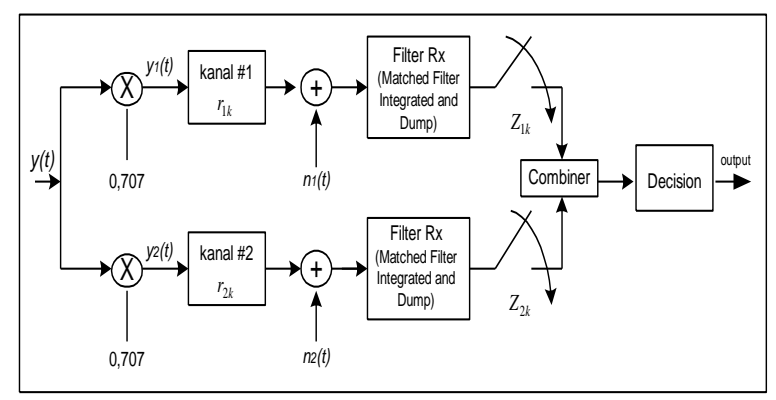

Gambar 4. Model Sistem dengan Diversity Combining [4].

\subsubsection{Simulasi Kanal AWGN dan Fading Rayleigh}

Dari model tersebut diketahui bahwa $y(t)$ adalah sinyal yang dikirim berupa sinyal persegi yang sudah termodulasi BPSK. Pada sistem ini diasumsikan ada dua kanal sehingga sinyal $y(t)$ yang masuk pada kedua kanal tersebut akan menjadi $y_{1}(t)$ dan $y_{2}(t)$. Besarnya sinyal $y_{1}(t)$ dan $y_{2}(t)$ adalah sinyal $y(t)$ dibagi akar dari jumlah kanal [11] atau :

$$
y_{1}(t)=y_{2}(t)=0,707 \times y(t)
$$

Pada masing-masing kanal terdapat fading yang berdistribusi Rayleigh. Pengaruh dari fading ini akan merusak bentuk sinyal pada masing-masing kanal. Kemudian sinyal-sinyal yang terkena fading itu akan dipengaruhi pula oleh noise Gaussian $n_{1}(t)$ dan $n_{2}(t)$. Sinyal yang terkena fading dan noise ini selanjutnya masuk ke rangkaian matched filter integrated and dump guna mendapatkan sinyal dengan performansi yang lebih baik sehingga sinyal ini lebih menyerupai sinyal aslinya, dimana keluaran dari rangkaian ini yaitu $Z_{1 k}$ dan $Z_{2 k}$ yang merupakan inputan untuk rangkaian combining. Proses yang terjadi pada rangkaian ini tergantung dari teknik diversity combining yang digunakan, dimana hal ini akan dijelaskan pada sub bab berikutnya. Proses pada rangkaian decision adalah mendemodulasi sinyal keluaran dari rangkaian combining untuk memperoleh bit-bit yang diterima, selanjutnya dengan menggunakan metode Monte Carlo akan diprediksi besarnya BER [4].

Noise yang dibangkitkan pada sistem ini berdistribusi normal dengan mean $\mu$ adalah nol dan varian $\sigma^{2}$ sebesar No/2 [13].

$$
n_{k}(t) \sim N\left(0, \frac{N o}{2}\right)
$$

Besarnya varian dipengaruhi oleh harga No yang bervariasi sesuai dengan besarnya $S N R$ (Signal to Noise ratio) dan besar energi perbitnya $E b$. Hubungan dari parameterparameter ini ditentukan dengan persamaan [15]:

$$
S N R=\frac{E b}{N o}
$$

Selain itu kanal juga dipengaruhi oleh fading yang memiliki distribusi Rayleigh. Envelope sinyal fading yang dibangkitkan merupakan proses kompleks gaussian yang mempunyai bagian real yang independen dengan bagian imajinernya. Pada kanal radio mobil, distribusi Rayleigh secara umum dipakai untuk menggambarkan statistik perbedaan waktu dari envelope yang diterima untuk sebuah sinyal flat fading. Fading cepat merupakan Rayleigh fading karena fading ini terdistribusi mengikuti distribusi Rayleigh. Metode untuk membangkitkannya dapat diilustrasikan berikut [11]:

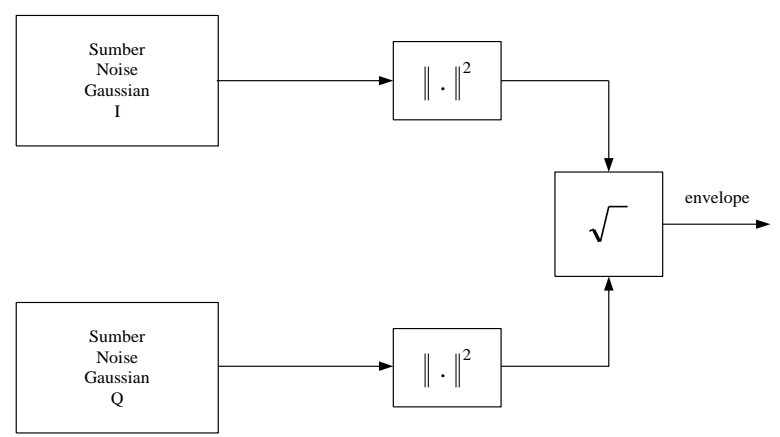

Gambar 5. Pembangkitan fading Rayleigh [5].

Dari gambar di atas terlihat bahwa $I_{g}(n)$ dan $Q_{g}(n)$ adalah komponen in-phase dan quadrature dari proses kompleks gaussian. Langkah-langkah dalam pembangkitan envelop fading ini adalah [14] : 


$$
\begin{aligned}
& I_{g}(n)=\operatorname{randn}(1, \text { panjang sinyal input }) \\
& Q_{g}(n)=\operatorname{randn}(1, \text { panjang sinyal input }) \\
& \text { envelope }=\sqrt{I_{g}(n)^{2}+Q_{g}(n)^{2}}
\end{aligned}
$$

Fading merupakan karakteristik utama dalam propagasi radio bergerak. Fading dapat didefenisikan sebagai perubahan fasa, polarisasi dan level dari suatu sinyal terhadap waktu. Defenisi dasar dari fading yang paling umum adalah yang berkaitan dengan mekanisme propagasi yang melibatkan refraksi, refleksi, difraksi, hamburan, dan redaman gelombang radio [9,12-13], Dari segi kualitas keberadaan fading dapat dirasakan sebagai timbul tenggelamnya suara yang terdengar dipenerima. Sinyal fading $r(t)$ merupakan gabungan dua komponen yaitu $r_{l}(t)$ dan $r_{o}(t), \quad r_{l}(t)$ disebut fading lambat, sedangkan $r_{o}(t)$ disebut fading cepat dengan persamaan [12-13] :

$$
r(t)=r_{l}(t)-r_{o}(t)
$$

sedang fading cepat diperoleh dari :

$$
r_{o}(t)=r(t)-r_{l}(t)
$$

Fading lambat adalah rata-rata sinyal fading $r_{l}(t)$ yang juga disebut dengan local mean. Fading lambat disebabkan adanya perubahan konfigurasi alam antara base station dengan unit bergerak yang akan menyebabkan fluktuasi path loss (redaman lintasan) akibat efek bayangan dari penghalang alam. Fading lambat sering disebut dengan shadowing. Fading cepat sering disebut juga dengan multipath fading [12]. Penyebab utama dari fading ini karena adanya lintasan ganda (multipath) akibat dipantulkannya gelombang oleh benda-benda seperti rumah, gedung, kendaraan, pohon dan benda-benda lain disekitar personal station yang menyebabkan sinyal menempuh suatu lintasan dari pemancar ke penerima. Selain itu Dengan adanya tambahan noise maka bentuk sinyal akan semakin rusak. Tipe fading ini merupakan tipe yang paling umum terjadi.

Karena perbedaan panjang lintasan yang ditempuh oleh lintasan pantul dan lintasan langsung, maka akan menyebabkan perbedaan amplitudo dan fasa dari kedua sinyal tersebut ketika diterima mobile station (MS). Dalam keadaan yang ekstrim dimana sinyal sama dan beda fasa $180^{\circ}$, maka sinyal akan saling meniadakan atau sinyal total adalah nol, sebaliknya bila fasanya sama, maka sinyal merupakan jumlah dari kedua sinyal yang datang tersebut [15].

Fading yang dibangkitkan dalam simulasi ini konstan sepanjang satu interval bit, dimana jumlah sampel fading yang dibangkitkan sama dengan jumlah bit input. Disamping itu nilai $r m s$ fading $E\left\{R^{2}\right\}$ adalah 1, serta fadingnya hanya pada amplitudo sinyalnya saja [12].

Adanya fading akan mengganggu sinyal yang masuk ke masing-masing kanal, dimana yang terjadi berupa proses perkalian antara envelope fading dengan sinyal yang ditransmisikan. Dengan adanya tambahan noise maka bentuk sinyal akan semakin rusak, serta kemungkinan kesalahan bit atau simbol yang terdeteksi pada penerima akan semakin besar. Bentuk hubungan pengaruh fading dan noise terhadap sinyal dapat diekspresikan dengan persamaan [12-14] :

$$
\begin{aligned}
& Z_{1}(t)=y_{1}(t) \cdot r_{1}(t)+n_{1}(t) \\
& Z_{2}(t)=y_{2}(t) \cdot r_{2}(t)+n_{2}(t)
\end{aligned}
$$

dimana: $y_{1}(t), y_{2}(t)$ adalah sinyal pada kanal 1 dan 2

$r_{l}(t), r_{l}(t)$ adalah fading pada kanal 1 dan 2

$n_{1}(t), n_{2}(t)$ adalah noise pada kanal 1 dan 2

\subsubsection{Rangkaian Decision}

$$
b_{k}^{\prime}= \begin{cases}1, & \text { jika } A_{k}^{\prime} \geq 0 \\ 0, & \text { jika } A_{k}^{\prime}<0\end{cases}
$$

Pada rangkaian decision terjadi proses decoding guna mendeteksi bit-bit pada sisi penerima, proses ini dilakukan dengan suatu aturan. Aturan tersebut memberikan performansi yang optimum, sehingga dapat dikurangi kesalahan yang terjadi [11].

\subsubsection{Perhitungan BER (Bit Error Rate)}

Metode simulasi Monte Carlo merupakan metode simulasi estimasi BER yang relatif sederhana, tapi memerlukan waktu running yang relatif lebih lama. Dimisalkan kondisi dimana 
dikirim 'nol' dan peluang bit salah bersyarat bila dikirim 'nol' didefinisikan [11]:

$$
P(\text { error /'nol' })=P o=\int_{V_{T}}^{\infty} f o(v) d v
$$

Dimana $V_{T}$ adalah tegangan threshold pada proses decision dan fo(v) adalah fungsi kerapatan peluang dari tegangan masukan pada saat pencuplikan bila bit yang dikirim adalah nol. Sehingga persamaan adalah [5] :

$$
P o=\int_{-\infty}^{\infty} h o(v) f o(v) d v
$$

dimana: $\quad h o(v)= \begin{cases}1, & \mathrm{v} \geq \mathrm{V}_{\mathrm{T}} \\ 0, & \mathrm{v}<\mathrm{V}_{\mathrm{T}}\end{cases}$

Persamaan tersebut ekivalen dengan persamaan berikut [11]:

$$
P o=E[h o(v)]
$$

Dan estimasi Po dari nilai yang diharapkan di atas adalah rata-rata sampel [5]:

$$
P o=\frac{1}{N} \sum_{i=1}^{N} h o\left(v_{i}\right)
$$

dimana $v_{i}$ sama dengan $v\left(t_{i}\right)$ dan $t_{i}$ adalah waktu spasi simbol dimana decision dilakukan. Lebih jelasnya, ho(v) adalah kesalahan yang terjadi, dan penjumlahan pada persamaan (28) adalah perhitungan jumlah kesalahan. Umumnya dalam sebuah sistem, dibangkitkan sebanyak $\mathrm{N}$ bit dan terdapat $\mathrm{n}$ bit yang salah, BER dihitung dengan menggunakan metode Monte Carlo, membandingkan antara urutan bit pada pengirim dengan urutan bit yang dideteksi melalui proses decoding pada sisi penerima. Umumnya dalam sebuah sistem jumlah bit yang salah $(n)$ dibagi dengan jumlah bit yang dibangkitkan $(N)$, sesuai dengan persamaan [5] :

$$
P e=\frac{n}{N}
$$

\subsection{Pembuatan program simulasi dalam bahasa MATLAB dan analisa hasil simulasi}

Penelitian yang dilakukan tidak dikerjakan pada kondisi nyata, melainkan simulasi keadaan nyata dengan menggunakan MATLAB. Metode ini dilakukan mengingat bahwa simulasi dalam desain sistem merupakan persiapan yang sangat penting sebagai suatu sarana untuk melakukan optimasi performansi dan reliabilitas sistem, serta untuk memeriksa ketepatan perancangan sebelum diimplementasikan pada keadaan nyata.

Metode simulasi yang digunakan adalah metode Monte Carlo. Dimana metode ini merupakan simulasi estimasi $B E R$ yang relatif sederhana, tapi memerlukan waktu running yang relatif lebih lama. Umumnya dalam sebuah sistem, dibangkitkan sebanyak $N$ bit dan terdapat $n$ bit yang salah. Kemudian setelah dilakukan running program maka dianalisa hasil dari simulasi tersebut.

\section{HASIL DAN PEMBAHASAN}

Tabel 1 menunjukkan harga $B E R$ pada masing-masing sistem.

Tabel 1. Harga BER dari setiap Sistem

\begin{tabular}{|c|c|c|}
\hline $\begin{array}{c}\text { Eb/No } \\
{[\mathbf{d B}]}\end{array}$ & $\begin{array}{c}\text { BER } \\
\text { Equal gain } \\
\text { Combining }\end{array}$ & $\begin{array}{c}\text { BER } \\
\text { Tanpa } \\
\text { Diversity }\end{array}$ \\
\hline 0 & 0,12747 & 0,14548 \\
\hline 1 & 0,10537 & 0,12693 \\
\hline 2 & 0,08529 & 0,10802 \\
\hline 3 & 0,06824 & 0,09032 \\
\hline 4 & 0,05102 & 0,07857 \\
\hline 5 & 0,03935 & 0,06498 \\
\hline 6 & 0,02922 & 0,05235 \\
\hline 7 & 0,02083 & 0,04351 \\
\hline 8 & 0,01476 & 0,03594 \\
\hline 9 & 0,00929 & 0,02948 \\
\hline
\end{tabular}

$B E R$ sebagai salah satu parameter dalam sistem komunikasi digital yang digunakan dalam menganalisa kinerja sistem. Cara penghitungan BER menggunakan metode Monte Carlo, yaitu dengan membandingkan antara urutan bit pada pengirim dengan urutan bit yang dideteksi melalui proses decoding pada sisi penerima.

Pada Gambar 6 menunjukkan hasil simulasi untuk mendapatkan perbandingan harga $B E R$ dari penerima dengan dan tanpa memakai equal gain combining. Dengan penggunaan teknik equal gain combining memberikan peningkatan kualitas sistem, dimana untuk penerima dengan equal gain combining, harga $B E R$ sebesar $0,05-$ 0,03 diperoleh dengan Eb/No sebesar 4,2-5,8 dB. Sedangkan pada penerima tanpa diversity, 
untuk memperoleh harga $B E R$ yang sama akan dibutuhkan Eb/No sekitar 6,3-8,8 dB. Sehingga diperoleh penghematan daya hampir dua kali bila dibandingkan dengan sistem tanpa diversity equal gain combining.

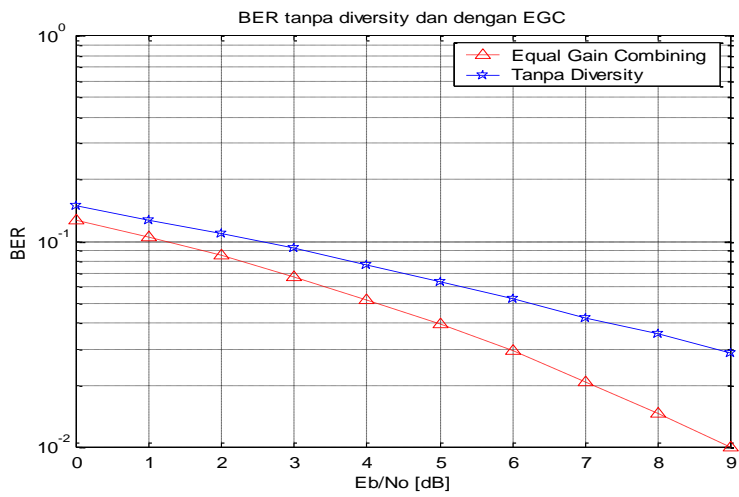

Gambar 6. Tanpa Diversity Vs Equal Gain Combining

\section{KESIMPULAN}

Kesimpulan dari hasil penelitian adalah adanya peningkatan kinerja yang lebih baik bila dibandingkan dengan sistem untuk penerima tanpa teknik equal gain combining. Pada penerima tanpa diversity, nilai $B E R \quad 0,05-0,03$ diperoleh dengan Eb/No sebesar 6,3-8,8 dB. Sedangkan pada penerima dengan diversity equal gain combining diperoleh $\mathrm{Eb} / \mathrm{No}$ sebesar 4,2-5,8 dB, dengan demikian terdapat penghematan daya sekitar 2 sampai $3 \mathrm{~dB}$.

\section{UCAPAN TERIMA KASIH}

Terima kasih disampaikan kepada Jurusan Teknik Elektro dan Fakultas Teknik Universitas Andalas yang telah memberikan dana peneilitian DIPA Fakultas Teknik dengan nomor kontrak : 004/UN.16.09.D/PL/2016.

\section{DAFTAR PUSTAKA}

[1]. Tuka, Veronika dan HS, Djati ,"Peran Jaringan Seluler untuk Komunikasi Data", Artikel Telekomunikasi Elektro Indonesia No.24, pp. 24-31, Tahun V (Januari 1999).

[2]. Hourani, Hafeth, "An Overview of Diversity Techniques in Wireless
Communication System", Helsinki University of Technology Communication Lab 2005

[3]. E. N. Gilbert, "Capacity of a burst-noise channel," Bell Syst. Tech. J., pp. 12531265, (Sept. 1960)

[4]. Baharuddin, "Peningkatan Unjuk Kerja Transmisi Citra Terkompresi Spiht Menggunakan Teknik Diversity Equal Gain Combining Pada Daerah Frekuensi Radio" Jurnal Saintek Vol X Nomor 1. Terakreditasi, No. ISSN 1410-8070, pp. 95-106 september 2007.

[5]. Vijaya Chandran Ramasami, "Simulation Project", EECS 865Project.

[6]. Imran Qaiser Sayed Waqar Mohsin, "Simulation of Diversity Techniques", Stanford University, 2001.

[7]. Baharuddin, "Transmisi Citra dengan Teknik Diversity pada Kanal Wireless", Thesis, Insitut Teknologi Sepuluh November, (Januari 2005).

[8]. Liane C. Ramac dan Pramod K. Varshney, "A Wavelet Domain Diversity Method for Transmission of Images over Wireless Channels", IEEE Journal On Selected Areas In Communication, Vol. 18, pp. 891-898 No. 6, (Juni 2000).

[9]. E. O. Elliott, "Estimates of error rates for codes on burst error channels," Bell Syst. Tech. J., vol. 42, p. 1977, (Sept. 1963).

[10]. Thomos Nikolaos, Boulgouris Nikolaos V, dan Strinzis Michael G, "Wireless Image Transmission Using Turbo Codes and Optimal Unequal Error Protection", IEEE Trans. On Image Processing Vol. 14 pp. 643-650 No.11 (November 2005).

[11]. Vijaya Chandran Ramasami, "BER Performance Over Fading Channels and Diversity Combining", EECS 862 Project, 2001.

[12]. P.G. Sherwood dan K. Zeger, "Error Protection for Progressive Image Transmission over Memoryless and Fading Channels", IEEE Trans. Commun., vol.46, pp. 1555-1559, Desember 1998

[13]. John. G. Proakis, , "Digital Communications", McGraw-Hill Series in Electrical and Computer Engineering, Third Ed. 1995. 
[14]. Theodore. S. Rappaport, "Wireless Communication Principles \& Practice", Prentice-Hall Communications Engineering and Emerging Technologies Series , 1996.

[15]. Shanmugam, K. Sam, "Digital and Analog Communications Systems", Jhon Wiley and Sons, Inc., Wiley Series in Telecommunications. 1979.

[16]. Nazir, Mohammad, "Metode Penelitian", Jakarta : Ghalia Indonesia 1983.

\section{Biodata Penulis}

Baharuddin, adalah staf pengajar Jurusan Teknik Elektro Fakultas Teknik Universitas Andalas Padang. Lulus Program Sarjana pada tahun 1993 pada Bidang Teknik Telekomunikasi dan Elektronika Jurusan Teknik Elektro Fakultas Teknik Universitas Hasanuddin. Lulus program Master pada Bidang Teknik Telekomunikasi Multimedia di ITS Surabaya tahun 2005.

Ondri Yudha Rusli, adalah Mahasiswa teknik Elektro dengan no. BP 01075051, dan tamat di Jurusan Teknik Elektro tahun 2006 pada bidang Telekomunikasi. E-mail : ondriyudha@yahoo.com 